Originalartikkel

\title{
Komplikasjoner etter gastrokirurgiske operasjoner
}

\begin{abstract}
Sammendrag
Bakgrunn. Kvaliteten på vår virksomhet kan ikke kun evalueres ut fra komplikasjoner under selve sykehusoppholdet, også forløpet de første ukene etter utskrivning fra avdelingen må tas med i vurderingen.
\end{abstract}

Materiale og metode. I komplikasjonsregisteret ved kirurgisk avdeling, Sørlandet sykehus, registreres komplikasjoner og reoperasjoner under selve oppholdet samt innen 30 dager etter utskrivning. For perioden 1.10. 2004-31.9. 2007 ble disse data analysert for de vanligste gastrokirurgiske inngrep.

Resultater. Fire typer inngrep skilte seg ut med høy andel komplikasjoner under både sykehusoppholdet og i 30-dagersperioden etter utskrivning: refluksinngrep ( $24 \%$ og $11 \%$ ), inngrep på ventrikkel/duodenum $140 \%$ og $12 \%)$, tynntarms- og tykktarmsinngrep ( $26 \%$ og $13 \%$ ) og endetarmsinngrep (26\% og $18 \%$ ). For bukveggsinngrep og kolecystektomier var andelen sykehuskomplikasjoner ( $7 \%$ respektive $5 \%$ ) og 30-dagerskomplikasjoner (7\% respektive $4 \%$ ) tilnærmet lik. Ved appendektomier og analinngrep, derimot, var andelen 30-dagerskomplikasjoner ( $5 \%$ respektive $3 \%$ ) høyere enn andelen sykehuskomplikasjoner (3\% respektive $2 \%$ ). Totalt sett ble nærmere $90 \%$ av de registrerte 30 dagerskomplikasjonene håndtert ved kirurgisk avdeling/poliklinikk i Kristiansand. Mer enn halvparten inntreffer den første uken etter utskrivning, en firedel i uke 2, resten i 3. eller 4. uke etter utskrivning. Mønsteret varierer gruppene imellom.

Fortolkning. Kortere liggetid i kirurgisk avdeling gjør at man for enkelte inngrep nå fanger opp flere komplikasjoner etter utskrivning enn under oppholdet. Oversikt over 30-dagerskomplikasjoner gir betydelig tilleggsinformasjon om avdelingens kvalitet.

\section{Eirik Sundlisæter*}

Odd Mjåland

odd.mjaland@c2i.net

Gastrokirurgisk seksjon

Kirurgisk avdeling

Sørlandet sykehus Kristiansand

4604 Kristiansand

* Nåværende adresse:

$\emptyset$ yeavdelingen

Oslo universitetssykehus, Ullevål 0407 Oslo

Komplikasjoner etter utskrivning fra en kirurgisk avdeling fører ofte til ny kontakt med sykehuset, som regel i løpet av de første ukene (1). 30-dagersreinnleggelsesrater er foreslått som indikator på behandlingskvaliteten (2). Siden dette sannsynligvis er en sammensatt problemstilling, er det reist tvil om hvorvidt reinnleggelsesraten er en god indikator alene (3). Dersom pasienter med øt risiko for reinnleggelse kan identifiseres før de skrives ut, kan eventuelle tiltak settes inn for å hindre både dette og ledsagende morbiditet.

Økende bruk av dagkirurgi samt akselererte pasientforløp (fast track-kirurgi) krever stor oppmerksomhet rettet mot komplikasjoner etter utskrivning. Veldokumenterte medisinske fordeler understøtter moderne kirurgisk utskrivningspraksis, men økonomiske og driftsmessige forhold kan i enkelte tilfeller vanskeliggjøre balansegangen mellom tidlig utskrivning versus forlenget opphold. Følgelig vil kjennskap til reinnleggelsesratene ved en avdeling være viktig $\mathrm{i}$ en løpende kvalitetssikring.

Hensikten med denne studien var å få en oversikt over komplikasjoner i løpet av primæroppholdet og innen 30 dager etter utskrivning for gastrokirurgiske pasienter operert ved Sørlandet sykehus Kristiansand i en treårsperiode.

\section{Materiale og metode}

I perioden 1.10. 2004-1.9. 2007 ble 2331 pasienter registrert $\mathrm{i}$ avdelingens eget komplikasjonsregister med operasjonskodene JA, JB, JD, JE, JF, JG, JH og JK i henhold til NCSP (4). Registeret ble opprettet som en intern kvalitetsregistrering høsten 2004 etter mønster av tilsvarende ved Gastrokirurgisk seksjon, Kirurgisk klinikk, Sykehuset i Vestfold. Personvernombudet godkjente opprettingen. Både pasienter med komplikasjoner under sykehusoppholdet og pasienter med komplikasjoner innen 30 dager etter utskrivning ble identifisert.

Komplikasjoner under sykehusoppholdet ble registrert fortløpende og prospektivt $\mathrm{i}$ forbindelse med previsitt, 30-dagerskomplikasjonene ved manuell gjennomgang av sykehusets elektroniske database (DIPS) drøye 30 dager etter utskrivning. En 30dagerskomplikasjon ble her definert som en øyeblikkelig hjelp-innleggelse ved en av Sørlandet sykehus' avdelinger i Kristiansand, Arendal eller Flekkefjord eller en ikkeplanlagt poliklinisk konsultasjon ved en av sykehusets poliklinikker innen 30 dager etter utskrivning. Hver komplikasjon ble klassifisert i en av følgende seks kategorier: «sårruptur», «smerter», «andre» (et bredt spekter av kirurgiske og medisinske komplikasjoner), «dyp infeksjon» (involverer dypt bløtvev, dvs. fascie og muskellag samt indre organ eller hulrom), «subileus/ileus» (delvis passasjehinder i tarmen som løste seg av seg selv/ fullstendig blokkering av tarmen som krevde operativ behandling) og «overflatisk infeksjon» (involverer kun hud og subkutant vev).

En sekretær tilknyttet registeret førte inn alle 30-dagerskomplikasjoner, som så senere ble kontrollert og klassifisert av registeransvarlig lege (B-grenkandidat) før endelig registrering i databasen. Planlagte polikliniske kontroller ble ikke registrert, med mindre det under en slik ble oppdaget en komplikasjon. Det ble jevnlig gjort kontroller med tanke på komplett registrering. Sammenholdt med operasjonslister hentet ut fra DIPS ble mer enn $90 \%$ av avdelingens operasjoner for de aktuelle pasientgrupper registrert.

Komplikasjoner ved primæroppholdet ble registrert og undersøkt med tanke på eventuell sammenheng med senere 30-dagerskomplikasjoner ved hjelp av khikvadrattest eller Fishers

\section{Hovedbudskap}

- 30-dagerskomplikasjoner etter gastrokirurgiske operasjoner varierer i hyppighet og alvorlighetsgrad avhengig av inngrepets omfang og pasientpopulasjon

- Halvparten av komplikasjonene inntreffer i løpet av 1. postoperative uke

- Kun når det gjaldt endetarmsinngrep. predikerte sykehuskomplikasjoner komplikasjoner etter utskrivning 
eksakte test, hvor $\mathrm{p}<0,05$ ble brukt som statistisk signifikans.

\section{Resultater}

Pasientkarakteristika er angitt i tabell 1. Av totalt 2331 pasienter hadde $265(11 \%)$ minst én komplikasjon i løpet av primæroppholdet. Inngrep på ventrikkel/duodenum, tynn- og tykktarm og endetarm og refluksinngrep var gruppene med høyest andel komplikasjoner i løpet av primæroppholdet (40\%, 26\%, 26\% og $24 \%$ ). Kun for pasienter med endetarmsinngrep fant vi en statistisk signifikant sammenheng mellom komplikasjoner i løpet av primæroppholdet og senere 30-dagerskomplikasjoner, $\mathrm{p}=0,04$.

177 pasienter ( $8 \%$ ) hadde en 30-dagerskomplikasjon - prosentandel for de enkelte pasientgrupper presenteres i tabell 2. Endetarmsinngrep, tynntarms- og tykktarmsinngrep, inngrep på ventrikkel/duodenum samt refluksinngrep ga størst andel 30-dagerskomplikasjoner. De fleste ble håndtert av Kirurgisk avdeling i Kristiansand, enten ved innleggelse $(68 \%)$ eller poliklinisk (18\%). De resterende $14 \%$ av 30-dagerskomplikasjonene ble håndtert ved medisinsk eller nevrologisk avdeling i Kristiansand eller ved en av Sørlandet sykehus' avdelinger i Arendal eller Flekkefjord. Tynntarms- og tykktarmsinngrep, inngrep på ventrikkel/duodenum og endetarmsinngrep var det som ga størst andel reinnleggelser ved andre avdelinger. I gruppen bukveggsinngrep og tynntarms- og tykktarmsinngrep ble $35 \%$ og $19 \%$ av komplikasjonene håndtert poliklinisk.

De fleste 30-dagerskomplikasjoner (56\%) inntraff første uken etter utskrivning, $26 \%$ kom i andre uke, $11 \%$ i tredje og $6 \%$ i fjerde uke. Nest etter gruppen «andre» (tab 3), som var vanligste årsaker til 30-dagerskomplikasjoner i første, andre og tredje uke $(28 \%$, $41 \%$ og $40 \%$ ), var de hyppigste årsakene $\mathrm{i}$ første uke smerter $(20 \%)$ og i andre uke over-

Tabell 1 Pasientkarakteristika. Antall opererte for de ulike typer inngrep, kiønnsfordeling median alder, andel operert som øyeblikkelig hjelp og median postoperativ liggetid. For median alder og median postoperativ liggetid er spredning angitt (laveste-høyeste alder/antall døgn)

\begin{tabular}{|c|c|c|c|c|}
\hline Organsystem/Inngrep & $\begin{array}{l}\text { Totalt antall } \\
\text { opererte } \\
\text { (prosent menn) }\end{array}$ & $\begin{array}{l}\text { Median alder } \\
\text { (spredning) }\end{array}$ & $\begin{array}{c}\text { Andel } \\
\text { øyeblikkelig } \\
\text { hjelp (\%) }\end{array}$ & $\begin{array}{l}\text { Median post- } \\
\text { operativ liggetid } \\
\text { (spredning) }\end{array}$ \\
\hline Bukveggsinngrep & 609 (69) & $57(0-82)$ & 30 & $1(0-44)$ \\
\hline Refluksinngrep & $37(76)$ & $42(1-75)$ & 8 & $2(1-18)$ \\
\hline $\begin{array}{l}\text { Inngrep på magesekk } \\
\text { og tolvfingertarm }\end{array}$ & $83(58)$ & $66(0-94)$ & 43 & $8(0-59)$ \\
\hline Appendektomier & 380 (49) & $25(3-91)$ & 94 & $2(0-32)$ \\
\hline $\begin{array}{l}\text { Tynntarms- og tykktarms- } \\
\text { inngrep }\end{array}$ & $453(52)$ & $68(1-98)$ & 40 & $7(0-122)$ \\
\hline Endetarmsinngrep & $114(60)$ & 70 (18-93) & 4 & $8(0-49)$ \\
\hline Analinngrep & $292(49)$ & $43(1-102)$ & 27 & $0(0-31)$ \\
\hline Kolecystektomier & 363 (31) & $49(15-89)$ & 16 & $1(0-34)$ \\
\hline
\end{tabular}

flatisk infeksjon (26\%). I tredje uke var årsakene likt fordelt mellom subileus/ileus, smerter, dyp infeksjon og overflatisk infeksjon $(15 \%$ hver), i fjerde uke var det smerter $(55 \%)$.

28 pasienter $(1 \%)$ døde som følge av en eller flere komplikasjoner. Av disse fikk 26 en komplikasjon i løpet av primæroppholdet, de siste to døde etter reinnleggelse. Dette var stort sett eldre pasienter, gjennomsnittsalderen var 80,5 år (63-92 år). 23 ble operert som øyeblikkelig hjelp. Vanligste komplikasjon som førte til døden var pneumoni, etterfulgt av hjerteinfarkt. Tidspunkt for samt årsak til 30-dagerskomplikasjoner etter utskrivning fra primæropphold for de enkelte grupper er angitt i figur 1.

\section{Diskusjon}

Økende bruk av dagkirurgi og akselererte pasientforløp medfører at stadig flere sendes hjem før en eventuell komplikasjon har gitt seg til kjenne. For eksempel utføres elektive bukveggsinngrep og analinngrep i dag hovedsakelig som dagkirurgi. Videre er postoperativ liggetid både ved ukomplisert elektiv kolecystektomi og ved ikke perforert appendisitt median ett døgn. Dette kan medføre at inngrepet bagatelliseres, med den følge at både pasient og lege undervurderer enkelte komplikasjoners alvorlighetsgrad. Våre tall på 30-dagerskomplikasjoner for kolecystektomier må sies å være akseptable og på linje med det man har registrert ved andre sykehus.

I en studie fra USA var det en 31-dagers postoperativ reinnleggelsesrate på $3,7 \%$ etter både åpen og laparoskopisk kolecystektomi (5), mens det etter laparoskopisk kolecystektomi (ukjent oppfølgingstid) ved Oslo universitetssykehus, Ullevål, ble rapportert en rate på $6,6 \%$ (6). For kolecystektomier forekom kun mindre alvorlige komplikasjoner, som overflatisk sårinfeksjon og smerteproblemer, etter 7. postoperative dag - tilsvarende 8. postoperative dag for appendektomier, 12.

Tabell 2 Komplikasjoner i løpet av primæroppholdet og innen 30 dager etter de vanligste gastrokirurgiske inngrep i perioden 1.10. 2004-31.9. 2007 ved Sørlandet sykehus Kristiansand. De tre kolonnene til høyre angir hvordan pasientene med komplikasjoner innen 30 dager ble håndtert; reinnleggelse eller poliklinisk behandling ved kirurgisk avdeling i Kristiansand eller en av Sørlandet sykehus' øvrige avdelinger i Kristiansand, Arendal eller Flekkefjord

\begin{tabular}{|c|c|c|c|c|c|c|c|c|}
\hline $\begin{array}{l}\text { Organsystem/ } \\
\text { inngrep }\end{array}$ & $\begin{array}{l}\text { Totalt } \\
\text { antall } \\
\text { opererte }\end{array}$ & $\begin{array}{l}\text { Komplika- } \\
\text { sjoner under } \\
\text { primær- } \\
\text { opphold (\%) }\end{array}$ & $\begin{array}{l}\text { Komplika- } \\
\text { sjoner } \\
\text { innen } \\
30 \text { dager (\%) }\end{array}$ & $\begin{array}{l}\text { Sammenheng } \\
\text { komplikasjoner } \\
\text { i løpet av pri- } \\
\text { mæropphold og } \\
\text { innen } 30 \text { dager } \\
\text { (p-verdi) }\end{array}$ & $\begin{array}{l}\text { Mortalitet } \\
\text { i løpet av pri- } \\
\text { mæropphold/ } \\
30 \text { dager } \\
\text { (antall) }\end{array}$ & $\begin{array}{c}\text { Reinnleggelse } \\
\text { kirurgisk avde- } \\
\text { ling }(\%)\end{array}$ & $\begin{array}{l}\text { Håndtert } \\
\text { polikli- } \\
\text { nisk (\%) }\end{array}$ & $\begin{array}{l}\text { Reinnleggelse } \\
\text { andre avde- } \\
\text { linger (\%) }\end{array}$ \\
\hline Bukveggsinngrep & 609 & 7 & 7 & 0,17 & $7 / 1$ & 57,5 & 35 & 7,5 \\
\hline Refluksinngrep & 37 & 24 & 11 & 0,24 & $0 / 0$ & 100 & 0 & 0 \\
\hline $\begin{array}{l}\text { Inngrep på magesekk } \\
\text { og tolvfingertarm }\end{array}$ & 83 & 40 & 12 & 0,51 & $6 / 0$ & 80 & 0 & 20 \\
\hline Appendektomier & 380 & 3 & 5 & 0,99 & $0 / 0$ & 85 & 15 & 0 \\
\hline $\begin{array}{l}\text { Tynntarms- og tykk- } \\
\text { tarmsinngrep }\end{array}$ & 453 & 26 & 13 & 0,06 & $13 / 1$ & 55 & 19 & 26 \\
\hline Endetarmsinngrep & 114 & 26 & 18 & 0,04 & $0 / 0$ & 75 & 10 & 15 \\
\hline Analinngrep & 292 & 2 & 3 & 1,00 & $0 / 0$ & 90 & 10 & 0 \\
\hline Kolecystektomier & 363 & 5 & 4 & 0,17 & $1 / 0$ & 87 & 6,5 & 6,5 \\
\hline
\end{tabular}


Tabell 3 Årsaker til komplikasjoner innen 30 dager etter utskrivning i gruppen «andre»

\begin{tabular}{ll}
\hline Diagnose & Antall pasienter \\
\hline Dehydrering & 6 \\
\hline Lungeemboli & 5 \\
\hline Redusert allmenntilstand & 5 \\
\hline Blødning/hematom & 3 \\
\hline Fistel & 3 \\
\hline Hjertesvikt & 3 \\
\hline Pneumoni & 3 \\
\hline Anastomoselekkasje & 2 \\
\hline Dyp venetrombose & 2 \\
\hline Gastroenteritt & 2 \\
\hline Hjerteinfarkt & 2 \\
\hline Kvalme & 2 \\
\hline Obstipasjon & 2 \\
\hline Serom & 2 \\
\hline Urinveisinfeksjon & 2 \\
\hline Angina pectoris & 1 \\
\hline Atrieflimmer & 1 \\
\hline Brystsmerter & 1 \\
\hline Cerebralt infarkt & 1 \\
\hline Empyem & 1 \\
\hline Epididymitt & 1 \\
\hline Hernie & 1 \\
\hline Hodepine & 1 \\
\hline Respirasjonssvikt & 1 \\
\hline Stomilekkasje & 1 \\
\hline Stominekrose & 1 \\
\hline Supraventrikulær takykardi & 1 \\
\hline Ventrikkelretensjon & 1 \\
\hline
\end{tabular}

postoperative dag for bukveggsinngrep og 22. postoperative dag ved analinngrep.

Fortløpende registrering av komplikasjoner under sykehusoppholdet og 30-dagerskomplikasjoner vil kunne avdekke endringer som kan peke i retning av behov for korreksjon i indikasjonsstilling, operasjonsteknikk samt perioperative forhold. Intraabdominale komplikasjoner ved alle laparoskopiske prosedyrer skal fanges opp tidligst mulig, men noen absolutt tidsgrense for når slike kan utelukkes, kan ikke angis - verken ut fra vårt materiale eller fra litteraturen. Utover subileustilstander, alle registrert $\mathrm{i}$ løpet av 1. postoperative uke, forekom det i vårt materiale ingen laparoskopirelaterte komplikasjoner etter utskrivning.

Også refluksoperasjoner utføres i dag med kort postoperativ liggetid. Reinnleggelse for dehydrering 7. postoperative dag og ventrikkelretensjon 22. postoperative dag peker i retning av at denne pasientgruppen må informeres grundig og muligens følges tettere med postoperative kontroller, alternativt bør de ha en «hotline» til operatøren de nærmeste ukene etter inngrepet. Ved Oslo universitetssykehus, Ullevål, har man i over ti år gjort laparoskopiske refluksoperasjoner dagkirurgisk. For 113 opererte pasienter er det rapportert en reinnleggelsesrate på 8,0\% (6), altså noe lavere enn våre tall (ukjent oppfølgingstid). Det må presiseres at antallet $\mathrm{i}$ vårt materiale er begrenset.

Verken når det gjaldt bukveggsinngrep, analinngrep eller kolecystektomier avdekket vi noen tidsrelatert komplikasjonstopp som skulle tilsi at disse inngrepene helst burde utføres på spesielle ukedager med tanke på bedre oppfølging. Etter tyngre operasjoner som tynntarms- og tykktarmsinngrep, ventrikkel-/duodenalinngrep og endetarmsinngrep ble komplikasjonene også fanget opp innen de første to ukene, men deres alvorlighetsgrad betinger ofte behov for kirurgisk spisskompetanse. Av den grunn bør således større elektiv kirurgi på disse områdene ikke utføres tett opp til perioder med svekket overlegebemanning. Overføring av enkeltinngrep til samarbeidende sykehus kan derfor i enkelttilfeller være fornuftig like forut for lengre ferieperioder.

Anastomoselekkasjer er en av gastrokirurgiens fryktede komplikasjoner. Det er ikke lenger uvanlig at også eldre pasienter utskrives 2 . eller 3 . postoperative døgn etter eksempelvis en laparoskopisk sigmoideumreseksjon eller hemikolektomi. Vårt materiale består i stor grad av åpne tarmreseksjoner og gjenspeiler ikke de siste års laparoskopiske aktivitet og akselererte pasientforløp. Vi fant to reinnleggelser knyttet til anastomoselekkasjer, i etterkant kan tidspunktet for begge utskrivningene diskuteres. "When in doubt don't throw them out» bør være en kjøreregel. En dansk undersøkelse vedrørende colonkirurgi (7) viste at planlagt utskrivning 3. postoperative dag ga færre reinnleggelser enn utskrivning 2. postoperative dag. Diagnostisk forsinkelse ved anastomoselekkasjer kan være svært alvorlig. Grundig informasjon til pasient og pårørende vedrørende slike komplikasjoner er av stor betydning, spesielt ved akselererte pasientforløp. Fortsatt må man regne med at opp mot halvparten av slike komplikasjoner vil bli oppdaget etter utskrivning fra sykehuset (8). For et sykehus med et opptaksområde på 200000 mennesker bør allikevel ikke dette tilsi noe særlig enn én gang per år i gjennomsnitt.

For pasienter der det er gjort tarmreseksjoner, ventrikkel-/duodenalinngrep samt endetarmsinngrep var det en relativt høy andel reinnleggelser ved andre avdelinger, noe som kan være relatert til høyere alder med dertil høyere prevalens av komorbiditet. Det var imidlertid kun for endetarmsinngrep det var statistisk signifikant sammenheng mellom komplikasjoner i løpet av primæroppholdet og 30-dagerskomplikasjoner. Det ligger utenfor intensjonen med denne studien å isolere enkeltfaktorer som kan predikere reinnleggelse. Med små og sammensatte pasientgrupper, som i tillegg er blitt behandlet $i$ en periode med betydelig endring i kirurgisk praksis, tror vi at det er lite å hente på en multivariat analyse av slike faktorer. Flere tidligere undersøkelser har vist at kols, funksjonsklasse (ASA-gruppe), steroidbruk samt bruk av antikoagulantia kan predikere reinnleggelse $(9,10)$.

Vi har ikke funnet tilsvarende totalmaterialer fra andre norske sykehus og har heller ingen tall fra tidligere år fra vårt eget arbeidssted (komplikasjonsregisteret ble først opprettet 1.10. 2004). For enkeltgrupper finnes det rikelig med både registerdata og materialer fra enkeltsykehus eller multisenterstudier. I en nordeuropeisk multisenterstudie var det en reinnleggelsesrate på 8,6\% innen 30 dager etter operasjonsdagen for elektiv åpen kolorektal kirurgi (11). I to studier fra USA var tallene $11,1 \%$ og $10,1 \%$ etter henholdsvis kolektomier (12) og kolorektal kirurgi (10). Liknende tall har man også fra Danmark (7). I en tysk studie (13) om rectumcancer var det $16 \%$, mens det for appendektomier (14) har vært oppgitt $5 \%$. Etter brokkirurgi (15) er det tidligere angitt $3 \%$ (28 dager postoperativt). I en norsk multisenterstudie der man sammenliknet det postoperative forløpet hos pasienter som fikk normal kost og hos dem som fikk tradisjonell ernæring via sonde etter øvre gastrointestinal kirurgi var det reinnleggelsesrater åtte uker etter utskrivning på henholdsvis $16,7 \%$ og 14,2 \% (16). Alle slike tall er avhengige av definisjoner, og vår betegnelse «30-dagerskomplikasjon», som fanger opp enhver sykehuskontakt innen 30 dager, kan gjøre sammenlikning vanskelig. Grensen mellom hva som er vanlige plager etter en operasjon og hva som er komplikasjoner kan også diskuteres.

Det finnes i dag flere medisinske kvalitetsregistre i Norge, både regionale og nasjonale. Selv om det ikke eksisterer noe nasjonalt register for komplikasjoner etter gastrointestinal kirurgi, har det lenge eksistert nasjonale registre for andre fagområder. Eksempler er Nasjonalt register for leddproteser, Norsk gynekologisk laparaskopiregister, Norsk karkirurgisk register og Sentralregister for hjerte-kirurgi i Norge. Ved hjelp av standard registreringsprosedyrer og målemetoder kan man si noe om behandlingskvaliteten ved de ulike sykehus og sammenlikne avdelinger med hverandre eller med landsgjennomsnittet. Registeret kan gi grunnlag for analyser og forskning. Dette kan videre være utgangspunkt for revisjon av gjeldende praksis, både hvordan og hvor selve behandlingen skal gjennomføres.

Ut fra analyser av det tidligere Rectumcancerregisterets data kom man f.eks. frem til at kun selekterte pasienter var tjent med preoperativ stråling, noe som dannet utgangspunkt for nye retningslinjer for behandling. Behandlingen av rectumcancer er videre blitt sentralisert til 30 sykehus, mot tidligere 55. Dette er en tendens man ser for flere typer kirurgi. Det er viktig at helsepolitiske beslutninger om sentralisering bygger på faglige vurderinger, ikke på udokumen- 
terte påstander. Nasjonale kliniske registre kan bidra til å avklare hva eventuelle forskjeller i behandlingsresultat sykehusene imellom skyldes. For enkelte segmenter innen gastrokirurgien finnes det større registre, f.eks. det nasjonale Colorectalcancerregisteret (tidligere Rectumcancerregisteret) og det regionale Register for komplikasjonsregistrering i gastrointestinal kirurgi ved St. Olavs hospital.

30-dagerskomplikasjoner ble i vårt materiale fulgt opp av kirurgisk avdeling i Kristiansand, enten som innleggelse eller som poliklinisk konsultasjon, i nesten ni av ti tilfeller. Det er likevel viktig å være oppmerksom på andre komplikasjoner som blir fanget opp ved andre sykehusavdelinger. I all hovedsak dreier det seg om komplikasjoner etter tynntarms- og tykktarmsoperasjoner, endetarmsinngrep og ventrikkel-/duodenalinngrep. Tilbakemeldinger ved reinnleggelser $i$ andre avdelinger blir ofte borte $i$ en travel klinisk hverdag, men med løpende registrering av 30-dagerskomplikasjoner kan man fange opp disse til bruk i undervisning og i kontinuerlig gjennomgang av avdelingens behandlings- og utskrivningspraksis. En høy andel av reinnleggelser ved eksempelvis lungeavdelingen vil kunne indikere mangelfull preoperativ forbehandling av kolspasienter eller manglende postoperativ lungefysioterapi.

Vår registrering av komplikasjoner etter utskrivning er basert på gjennomgang av sykehusets elektroniske database, og vil ikke fange opp eventuelle komplikasjoner registrert i primærhelsetjenesten eller ved sykehus utenfor Sørlandet. Sannsynligvis er denne andelen liten, men det er i vårt materiale en mulighet for mangelfull registrering.

I denne studien har vi evaluert tidspunkt og årsak til 30-dagerskomplikasjoner etter utskrivning etter ulike gastrokirurgiske operasjoner. Vi ønsket først og fremst å etablere et system for løpende kvalitetskontroll i en tid med store endringer knyttet til laparoskopisk kirurgi og akselererte pasientforløp. Ikke overraskende fant vi $i$ vårt materiale store forskjeller både i sykehuskomplikasjoner og i 30-dagerskomplikasjoner mellom de forskjellige prosedyregrupper. Inngrepets kompleksitet, pasientpopulasjonen og forskjeller i andelen elektiv kirurgi versus øyeblikkelig hjelp-kirurgi forklarer slike forskjeller. Gitt andel sykehuskomplikasjoner pluss 30-dagerskomplikasjoner som isolert kvalitetsindikator etterlater våre tall liten tvil om at dagens kirurgi holder et akseptabelt nivå.

Det er viktig at man ved den enkelte avdeling går tallene nærmere etter i sømmene for å fremme kvalitetsforbedrende tiltak og at man tilstreber standardisering for sammenlikning med andre avdelinger. De aktuelle tall vil være av interesse både for allmennpraktikeren som henviser samt for egen stab som, sammen med pasienten, skal fatte beslutning om et kirurgisk inngrep. Tallene lar
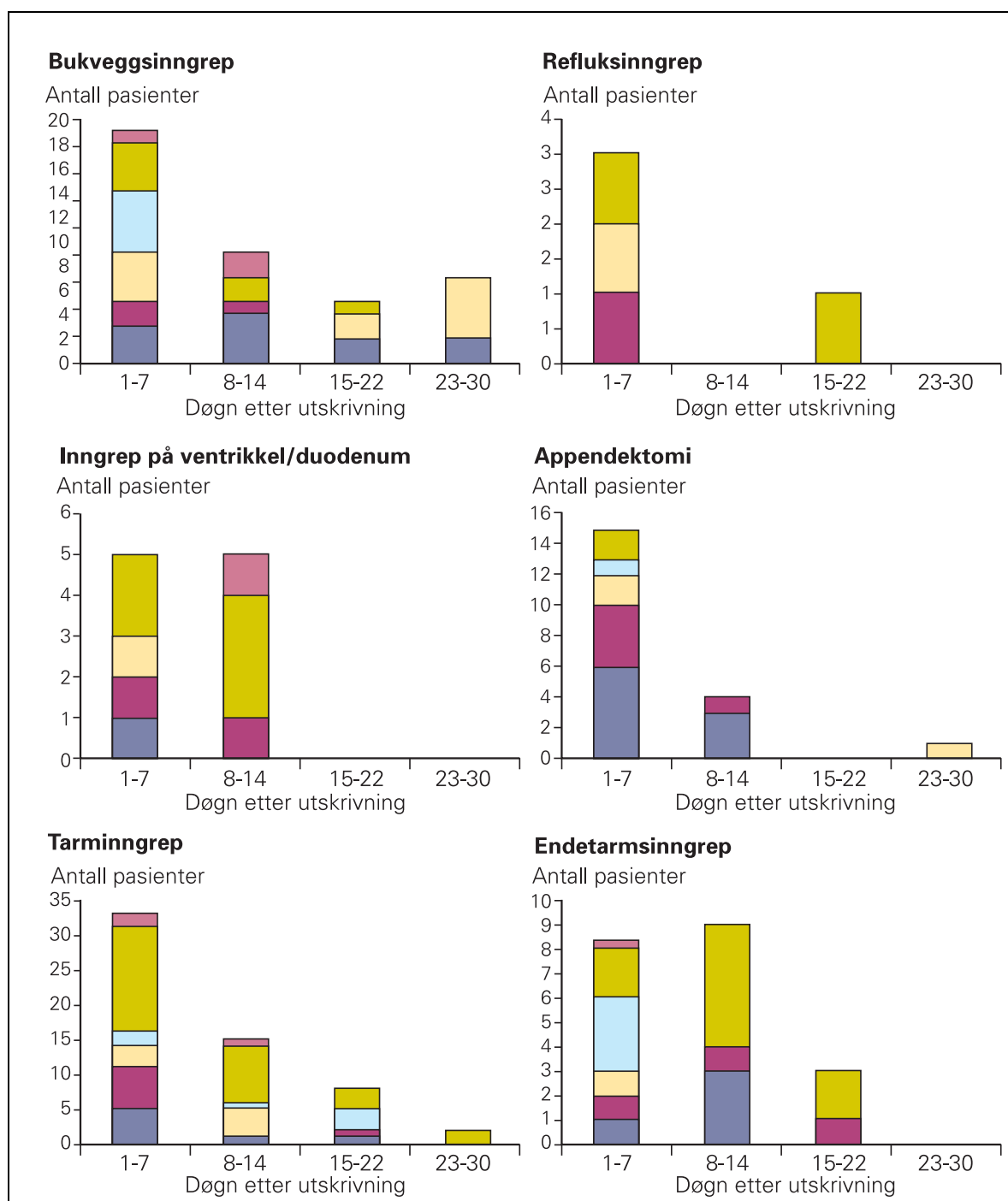

\section{Analinngrep}
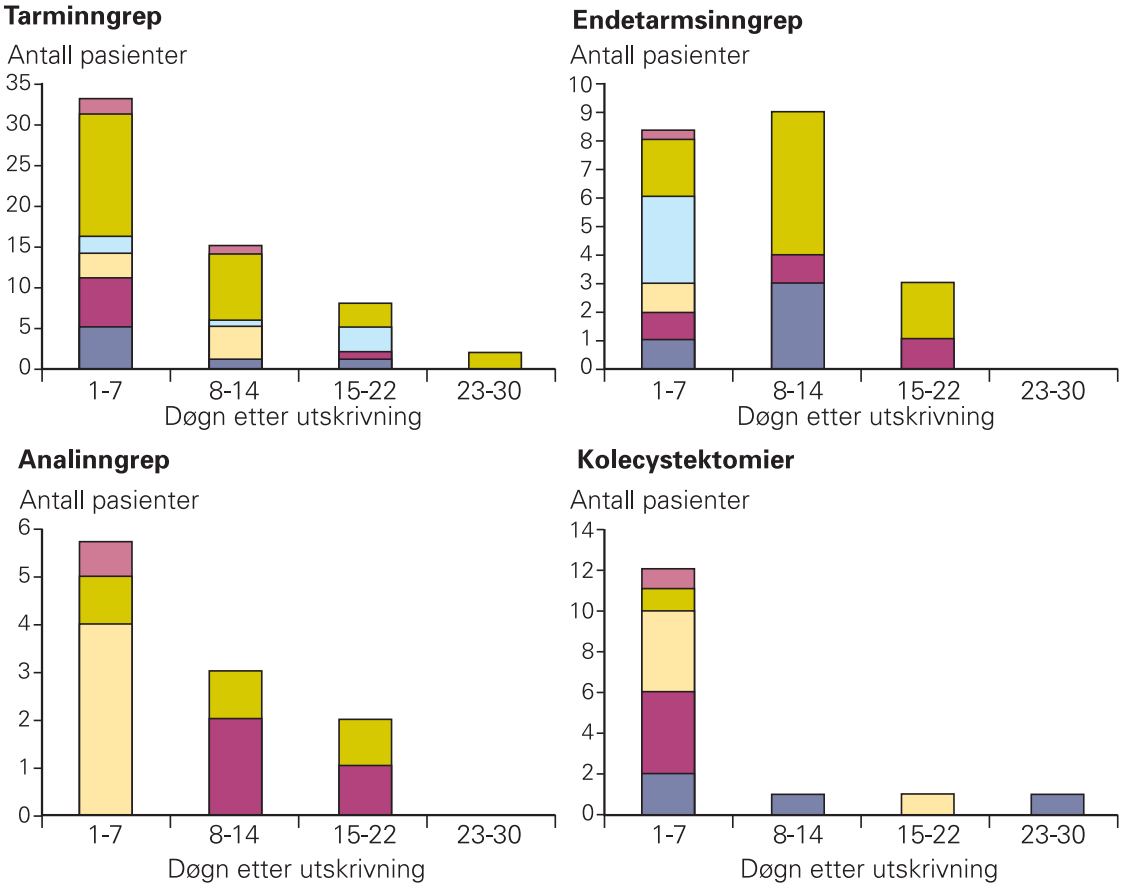

Kolecystektomier

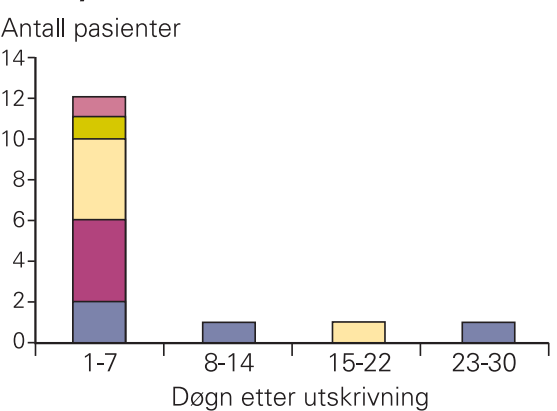

$\begin{array}{lll}\square \text { Sårruptur } & \square \text { Subileus/ileus } \\ \square \text { Andre } & \square \text { Dyp infeksjon } \\ & \text { Smerte } & \text { Overflatisk infeksjon }\end{array}$

Figur 1 Tidspunkt for og årsak til komplikasjoner innen 30 dager etter utskrivning fra primæropphold

seg med letthet hente ut f.eks. en gang årlig, og kan føres inn i skriftlig informasjonsmateriale til den enkelte pasient. Selvfølgelig bør de også ligge ute på avdelingens nettsider. Dagens pasienter bruker i økende grad Internett for å sjekke behandlingskvaliteten ved aktuelle sykehus, og det vil nok være betydelig enklere å takle en del pasientsamtaler både før og etter et inngrep med slike tall som basisverdier.
Oppgitte interessekonflikter: Ingen

Vi takker Olaf Johan Hartmann-Johnsen og Vibeke $\emptyset$ Østi for verdifulle bidrag til datainnsamlingen. 


\section{Litteratur}

1. Courtney ED, Ankrett S, McCollum PT. 28-Day emergency surgical re-admission rates as a clinical indicator of performance. Ann R Coll Surg Engl 2003; 85: 75-8.

2. Thomas JW, Holloway JJ. Investigating early readmission as an indicator for quality of care studies. Med Care 1991; 29: 377-94.

3. Benbassat J, Taragin M. Hospital readmissions as a measure of quality of health care: advantages and limitations. Arch Intern Med 2000; 160: 1074-81.

4. Klassifikasjon av medisinske prosedyrer og kirurgiske inngrep 2007. Klinisk prosedyrekodeverk. Oslo: Nomesko, KITH, Sosial- og helsedirektoratet, 2007.

5. Wolf AS, Nijsse BA, Sokal SM et al. Surgical outcomes of open cholecystectomy in the laparoscopic era. Am J Surg 2008; doi: 10.1016/j.amjsurg. 2008.05.010

6. Skattum J, Edwin B, Trondsen E et al. Outpatient laparoscopic surgery: feasibility and consequen ces for education and health care costs. Surg Endosc 2004; 18: 796-801.

7. Andersen J, Hjort-Jakobsen D, Christiansen PS et al. Readmission rates after a planned hospital stay of 2 versus 3 days in fast-track colonic surgery. Br J Surg 2007; 94: 890-3.

8. Byrn JC, Schlager A, Divino CM et al. The manage ment of 38 anastomotic leaks after 1684 intestinal resections. Dis Col Rectum 2006; 49: 1346-53.

9. Kariv Y, Wang W, Senagore AJ et al. Multivariable analysis of factors associated with hospital readmission after intestinal surgery. Am J Surg 2006; 191: $364-71$.

10. Kiran RP. Delaney CP. Senagore AJ et al. Outcomes and prediction of hospital readmission after intestinal surgery. J Am Coll Surg 2004; 198: 877-83

11. Hendry PO, Hausel J, Lassen K et al. Determinants of outcome after colorectal resection within an enhanced recovery programme. Br J Surg 2009; 96: 197-205.
12. Goodney PP. Delaney CP Senagore AJ et al. Hospital volume, length of stay, and readmission rates in high-risk surgery. Ann Surg 2003; 238: 161-7.

13. Schwenk W. Neudecker J, Raue W et al. «Fasttrack» rehabilitation after rectal cancer resection. Int J Colorectal Dis 2006; 21: 547-53.

14. Kirshtein B, Bayme M, Domchik S et al. Complicated appendicitis: laparoscopic or conventional surgery? World J Surg 2007; 31: 744-9.

15. Williams S, Bottle A, Aylin P. Length of hospital stay and subsequent emergency readmission. BMJ 2005; 331: 371

16. Lassen $\mathrm{K}$, Kjæve J, Fetveit $\mathrm{V}$ et al. Allowing normal food at will after major upper gastrointestinal surgery does not increase morbidity. Ann Surg 2008; 247: $721-9$.

Manuskriptet ble mottatt 1.1. 2009 og godkjent 6.8. 2009. Medisinsk redaktør Åslaug Helland. 